CrossMark \&lick for updates

Cite this: Phys. Chem. Chem. Phys., 2016, 18, 9295

Received 10th November 2015, Accepted 3rd March 2016

DOI: $10.1039 / \mathrm{c} 5 \mathrm{cp} 06890 \mathrm{~h}$

www.rsc.org/pccp

\title{
Boosting water oxidation layer-by-layer $\dagger$
}

\author{
Jonnathan C. Hidalgo-Acosta, ${ }^{a}$ Micheál D. Scanlon, ${ }^{b}$ Manuel A. Méndez, ${ }^{a}$ \\ Véronique Amstutz, ${ }^{a}$ Heron Vrubel, ${ }^{a}$ Marcin Opallo ${ }^{c}$ and Hubert H. Girault*a
}

\begin{abstract}
Electrocatalysis of water oxidation was achieved using fluorinated tin oxide (FTO) electrodes modified with layer-by-layer deposited films consisting of bilayers of negatively charged citrate-stabilized $1 \mathrm{rO}_{2}$ NPs and positively charged poly(diallyldimethylammonium chloride) (PDDA) polymer. The $\operatorname{lrO}_{2} \mathrm{NP}$ surface coverage can be fine-tuned by controlling the number of bilayers. The $\mathrm{IrO}_{2} \mathrm{NP}$ films were amorphous, with the NPs therein being well-dispersed and retaining their as-synthesized shape and sizes. UV/vis spectroscopic and spectro-electrochemical studies confirmed that the total surface coverage and electrochemically addressable surface coverage of $\mathrm{IrO}_{2} \mathrm{NPs}$ increased linearly with the number of bilayers up to 10 bilayers. The voltammetry of the modified electrode was that of hydrous iridium oxide films (HIROFs) with an observed super-Nernstian $\mathrm{pH}$ response of the $\operatorname{Ir}(\mathrm{III}) / \mathrm{Ir}(\mathrm{IV})$ and $\operatorname{Ir}(\mathrm{IV})-\operatorname{Ir}(\mathrm{Iv}) / \operatorname{Ir}(\mathrm{IV})-\operatorname{Ir}(\mathrm{V})$ redox transitions and Nernstian shift of the oxygen evolution onset potential. The overpotential of the oxygen evolution reaction (OER) was essentially $\mathrm{pH}$ independent, varying only from $0.22 \mathrm{~V}$ to $0.28 \mathrm{~V}$ (at a current density of $0.1 \mathrm{~mA} \mathrm{~cm}{ }^{-2}$ ), moving from acidic to alkaline conditions. Bulk electrolysis experiments revealed that the $\mathrm{IrO}_{2}$ /PDDA films were stable and adherent under acidic and neutral conditions but degraded in alkaline solutions. Oxygen was evolved with Faradaic efficiencies approaching $100 \%$ under acidic $(\mathrm{pH} 1)$ and neutral $(\mathrm{pH} 7)$ conditions, and $88 \%$ in alkaline solutions $(\mathrm{pH} 13)$. This layer-by-layer approach forms the basis of future large-scale OER electrode development using ink-jet printing technology.
\end{abstract}

\section{Introduction}

The development of new routes towards the generation of environmentally friendly solar fuels, such as molecular hydrogen $\left(\mathrm{H}_{2}\right)$ and oxygen $\left(\mathrm{O}_{2}\right)$, for use in fuel cells is a significant grand challenge facing the scientific community. ${ }^{1-3}$ Water splitting, viewed as the sum of the hydrogen evolution reaction (HER) and oxygen evolution reaction (OER), represents one of the most promising, yet challenging, options in this regard. ${ }^{4-10}$ The HER is now achievable over a wide $\mathrm{pH}$ range at relatively

\footnotetext{
${ }^{a}$ Laboratoire d'Electrochimie Physique et Analytique (LEPA), École Polytechnique Fédérale de Lausanne (EPFL), Valais Wallis, Rue de l'Industrie 17, Case Postale 440, 1951 Sion, Switzerland. E-mail: hubert.girault@epfl.ch

${ }^{b}$ Department of Chemistry, the Tyndall National Institute and the Analytical \& Biological Chemistry Research Facility (ABCRF), University College Cork, Cork, Ireland

${ }^{c}$ Institute of Physical Chemistry, Polish Academy of Sciences, ul. Kasprazaka 44/52, 01-224 Warszawa, Poland

$\dagger$ Electronic supplementary information (ESI) available: UV/vis spectroscopy and TEM of colloidal as-synthesized $\mathrm{IrO}_{2}$ NPs, details of the "aging" of LbL deposited $\mathrm{IrO}_{2} / \mathrm{PDDA}$ bilayers on FTO electrodes under ambient conditions with time, image of the bulk electrolysis experimental setup, details of the experimental procedure to determine the Faradaic efficiency of the OER after bulk electrolysis at $\mathrm{IrO}_{2} / \mathrm{PDDA}$ bilayer-modified FTO electrodes in different $\mathrm{pH}$ conditions, and details of long term electrolysis experiments. See DOI: $10.1039 / \mathrm{c} 5 \mathrm{cp} 06890 \mathrm{~h}$
}

low overpotentials $(\eta)$ using earth abundant inorganic electrocatalysts. ${ }^{11-14}$ By comparison, the OER is considered the bottleneck of the overall water splitting process requiring the negotiation of multiple intermediary steps that in many cases are separated by significant energy barriers. ${ }^{15-17}$ Thus, the four-electron electrooxidation of water proceeds at potentials far in excess of the thermodynamic value, necessitating an efficient electrocatalyst.

Iridium oxide nanoparticles ( $\mathrm{IrO}_{2} \mathrm{NPs}$ ) exhibit high electrocatalytic activity at moderate overpotentials $(0.20-0.29 \mathrm{~V})^{18-24}$ and stability against anodic corrosion over a wide $\mathrm{pH}$ range, whether incorporated into electrochemical or photo-electrochemical OER systems. ${ }^{25-27}$ The scarcity of Ir and the enhanced activity of nanoscale (higher surface-to-volume ratio) ${ }^{28}$ versus bulk heterogeneous catalysts or solid $\mathrm{IrO}_{2}$ electrodes promotes the use of $\mathrm{IrO}_{2}$ as NPs, typically studied as colloidal solutions or films on various electrode surfaces.

The design of immobilization strategies to prepare stable, electrocatalytic high-surface area amorphous $\mathrm{IrO}_{2} \mathrm{NP}$ films that (i) maximize the surface coverage of electroactive catalytic $\mathrm{IrO}_{2}$ centers and (ii) simultaneously retain the properties of individual (as opposed to aggregated) NPs are key to the development of modified electrodes capable of promoting the OER at low overpotentials with high Faradaic efficiencies. Pre-formed $\mathrm{IrO}_{2}$ NPs from colloidal solutions have been attached to indium tin 
oxide (ITO), ${ }^{18,29-32}$ fluorinated tin oxide (FTO), ${ }^{21,32}$ gold, ${ }^{18,21,33}$ platinum (Pt), ${ }^{18,33}$ glassy carbon (GC), ${ }^{18,21-23,33}$ hematite $^{34}$ and spectroscopic graphite $(\mathrm{Gr})^{24}$ electrodes by chemisorption, ${ }^{31}$ physisorption, ${ }^{24}$ electroflocculation by either controlled potential amperometry (CPA) ${ }^{18,33}$ or dual-potential pulsed amperometry (DPPA), ${ }^{23}$ anodic electrodeposition, ${ }^{20,30,35}$ electrophoresis ${ }^{34}$ and electrostatic interactions. ${ }^{22}$ Additionally, $\mathrm{IrO}_{2} \mathrm{NP}$ films have been generated in situ by anodic electrolysis of $\left[\operatorname{Ir}(\mathrm{OH})_{6}\right]^{2-}$ solutions. $^{21}$

Importantly, different $\mathrm{IrO}_{2} \mathrm{NP}$ film formation strategies using the same colloid solutions affect (i) the electrocatalytic properties and (ii) the stability of the films formed post-deposition on an electrode surface. Ferapontova and co-workers immobilized water-capped $\mathrm{IrO}_{2} \cdot n \mathrm{H}_{2} \mathrm{O}$ NPs on graphite electrodes by both electrochemical deposition and physisorption. Their study revealed that the electrochemically deposited $\mathrm{IrO}_{2} \mathrm{NP}$ films exhibited a higher stability and activity than those physisorbed. ${ }^{24}$ Murray and co-workers originally developed an electroflocculation approach where the electrode is biased at potentials where the water oxidation reaction takes place. As a result, a significant amount of protons are produced at the electrode surface and cause the precipitation of hydroxyl-capped $\mathrm{IrO}_{2} \mathrm{NPs} .{ }^{18,33}$ Meanwhile, the copious $\mathrm{O}_{2}$ evolved during electroflocculation induced mesoporosity in the resulting adherent films. Chuang and co-workers revisited electroflocculation with the premise of using dual-potential pulsed amperometry (DPPA), the purpose of which was to intermittently reduce evolved $\mathrm{O}_{2}$ during electroflocculation to minimize the amount of gas at the electrode surface and promote adhesion of the $\mathrm{IrO}_{2} \mathrm{NPs}^{23}$ This change in electrochemical technique not only improved film stability but also changed the physical morphology (minimizing aggregation) and chemical composition of the films, thus altering the kinetics of the OER and also serving as an excellent example of the powerful influence of immobilization strategy when designing efficient OER electrodes.

Herein, we describe an alternative immobilization methodology to prepare $\mathrm{IrO}_{2}$ NP films on FTO as OER electrodes by layer-bylayer (LbL) deposition of alternate layers of oppositely charged poly(diallyldimethylammonium chloride) (PDDA) polymer and citrate stabilized $\mathrm{IrO}_{2}$ NPs on the electrode surface. This flexible approach allowed us to finely tune the number of electroactive iridium centers by incorporating additional layers, producing stable, amorphous $\mathrm{IrO}_{2} \mathrm{NP}$ films containing well-dispersed catalytic NPs. Furthermore, the use of stabilized particles allows us to obtain an electrochemical response which resembles the highly reversible waves observed in hydrous iridium oxide films (HIROFs), differing from the more irreversible behavior obtained in flocculated films. This behavior which remains across the whole pH scale is mainly attributed to the effect of the capping agent, which ensures that the number of electroactive sites remains approximately the same by avoiding the strong interaction between individual centers. To our knowledge, the only previous immobilization strategy involving purely electrostatic interactions was that reported by Chuang and co-workers who described the modification of glassy carbon electrodes with a positively charged polymer, poly(allylamine hydrochloride) (PAH), and its interaction with negatively charged hydroxyl-capped $\mathrm{IrO}_{2} \mathrm{NPs}^{22}$
The present approach lays the groundwork for future large-scale OER electrode development using ink-jet printing technology. ${ }^{36,37}$

\section{Experimental}

\section{Chemicals}

All chemicals were used as received without further purification. Potassium hexachloroiridate $\left(\mathrm{K}_{2} \mathrm{IrCl}_{6}, 99.99 \%\right)$, tri-sodium citrate dihydrate $(\geq 99.0)$, poly(diallydimethylammonium chloride) (PDDA, 20\%, $\left.M_{\mathrm{w}} 200000-350000\right)$ and perchloric acid $\left(\mathrm{HClO}_{4}\right.$, $70 \%$ ) were purchased from Aldrich. All aqueous solutions were prepared with ultrapure water (Millipore Milli-Q, specific resistivity $18.2 \mathrm{M} \Omega \mathrm{cm}$ ). Pure $\mathrm{O}_{2}$ (medical) cylinders were purchased from Carbagas.

\section{Synthesis of colloidal $\mathrm{IrO}_{2}$ NPs}

Colloidal citrate stabilized $\mathrm{IrO}_{2}$ NPs were synthesized as described by Mallouk and co-workers. ${ }^{7,10}$ Briefly, $0.0300 \mathrm{~g}$ of $\mathrm{K}_{2} \mathrm{IrCl}_{6}(6.20 \times$ $\left.10^{-5} \mathrm{~mol}\right)$ and $0.0547 \mathrm{~g}$ of tri-sodium citrate dihydrate $(1.86 \times$ $10^{-4} \mathrm{~mol}$ ) were dissolved in $50 \mathrm{~mL}$ of de-ionized water. The $\mathrm{pH}$ of this solution was adjusted to approximately 7.5 with $0.25 \mathrm{M}$ $\mathrm{NaOH}$. This brown solution was then transferred to a $100 \mathrm{~mL}$ round bottomed flask with a reflux condenser attached and heated at $95{ }^{\circ} \mathrm{C}$ in an oil bath. After 30 minutes the roundbottomed flask was removed from the oil bath and the solution allowed to cool down to room temperature. The $\mathrm{pH}$ of this solution was precisely adjusted to 7.5 with $0.25 \mathrm{M} \mathrm{NaOH}$. The heating at $95{ }^{\circ} \mathrm{C}$ for 30 minutes followed by addition of $\mathrm{NaOH}$ was repeated until the $\mathrm{pH}$ stabilized at 7.5. The solution was heated at $95{ }^{\circ} \mathrm{C}$ for a further 2 hours with $\mathrm{O}_{2}$ bubbling throughout. Finally, the colloidal $\mathrm{IrO}_{2} \mathrm{NP}$ solution was cooled to room temperature and dialyzed in deionized water using Spectra/ Pore 7 membranes with molecular weight cut-offs (MWCO) of $1 \mathrm{kDa}$. The dialysis was performed over a 24 hour period and the water changed at least four times. Post-dialysis, the colloidal solution was diluted to a total volume of $100 \mathrm{~mL}$ giving $0.62 \mathrm{mM}$ of colloidal citrate stabilized $\mathrm{IrO}_{2}$ NPs.

\section{Layer-by-layer (LbL) deposition of $\mathrm{IrO}_{2} \mathrm{NP}$ films on FTO electrodes}

Prior to deposition, the FTO slides ( $15 \Omega$ per sq, $2.2 \mathrm{~mm}$ thickness, Solaronix) were cleaned by sequential washing with acetone, sonication in a base bath $(1 \mathrm{M} \mathrm{KOH}$ in an ethanol/water mixture $(8: 2)$ ) for 20 minutes, rinsing with water, immersion in $1 \mathrm{M}$ $\mathrm{H}_{2} \mathrm{SO}_{4}$ for 15 minutes and, finally, treatment with $\mathrm{O}_{2}$ plasma for 15 minutes. In order to ensure reproducibility, the LbL deposition was controlled by a custom dip-coating robot with an arm capable of movement in an arc, as well as up-and-down in the $z$-direction perpendicular to the table. The LbL deposition sequence began by immersing the cleaned FTO electrode for 15 minutes in a solution containing the cationic polymer PDDA $(4.76 \% \mathrm{w} / \mathrm{v})$ in $0.4 \mathrm{M} \mathrm{NaCl}$. Next, the electrode was rinsed twice with water and subsequently immersed in a $0.62 \mathrm{mM}$ solution of colloidal citrate stabilized $\mathrm{IrO}_{2}$ NPs for 30 minutes. Finally, the $\mathrm{IrO}_{2} / \mathrm{PDDA}$-modified FTO electrode was rinsed twice in deionized water and allowed to air dry. 
The desired number of $\mathrm{IrO}_{2} / \mathrm{PDDA}$ bilayers were obtained by repeating the sequence the necessary number of times (see Movie S1 in the ESI $\dagger$ ).

\section{Characterization techniques}

The as-synthesized colloidal $\mathrm{IrO}_{2}$ NPs were characterized by UV/vis spectroscopy using an Ocean Optics USB 4000 optic fiber spectrophotometer and transmission electron microscopy (TEM) using a FEI CM12 (Phillips) transmission electron micro-

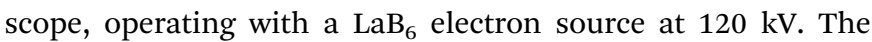
$\mathrm{IrO}_{2} /$ PDDA-modified FTO electrodes were also analyzed by high-resolution scanning electron microscopy (HR SEM) using a SEM MERLIN composed of a GEMINI II column (Zeiss). As discussed vide infra, prior to UV/vis measurements the $\mathrm{IrO}_{2} /$ PDDA-modified FTO electrodes were pre-treated by polarization at 0.635 vs. $\mathrm{SHE}$ (i.e., $0.425 \mathrm{~V}$ vs. $\mathrm{Ag} / \mathrm{AgCl}(3 \mathrm{M} \mathrm{NaCl})$ ) for $90 \mathrm{~s}$. Spectro-electrochemical characterization of the $\mathrm{IrO}_{2} / \mathrm{PDDA}$ modified FTO electrodes was performed in a three-electrode configuration using a PGSTAT 30 potentiostat (Metrohm, $\mathrm{CH}$ ). No $i \mathrm{R}$ compensation was applied to the cell and all voltammetry experiments were carried out under aerobic conditions at an ambient temperature of $23 \pm 2{ }^{\circ} \mathrm{C}$.

Bulk electrolysis experiments were carried out in aqueous solutions containing either $0.1 \mathrm{M} \mathrm{HClO}_{4}$ (pH 1), $0.5 \mathrm{M}$ phosphate buffer ( $\mathrm{pH} 7$ ) or $0.1 \mathrm{M} \mathrm{NaOH}$ ( $\mathrm{pH} 13)$. A classic bulk electrolysis cell configuration was employed using an $\mathrm{IrO}_{2} / \mathrm{PDDA}$-modified FTO electrode with $14 \mathrm{IrO}_{2} / \mathrm{PDDA}$ bilayers as the working electrode, Duocel ${ }^{\circledR}$ reticulated vitreous carbon $(\mathrm{RVC}$, pores/inch $=30$; relative density 3\%, supplied by ERG Aerospace Corporation, U.S.A.) as the counter electrode and $\mathrm{Ag} / \mathrm{AgCl}(3 \mathrm{M} \mathrm{NaCl})$ as the reference electrode. The anodic and cathodic compartments were separated by a glass wool plug to prevent re-oxidation of $\mathrm{O}_{2}$ at the RVC counter electrode. $\mathrm{O}_{2}$ measurements were carried out with a FOXY fluorescent $\mathrm{O}_{2}$ sensor from Ocean Optics. Prior to $\mathrm{O}_{2}$ measurements, the electrolysis cell was sonicated for approximately $20 \mathrm{~s}$. This permitted any $\mathrm{O}_{2}$ bubbles generated, but trapped, at the $\mathrm{IrO}_{2} / \mathrm{PDDA}$-modified FTO electrode surface to migrate to the headspace. As all electrolysis experiments were carried out under aerobic conditions, the $\% \mathrm{O}_{2}$ in air was regarded as the baseline and all $\mathrm{O}_{2}$ evolved was determined as the excess $\mathrm{O}_{2}$ measured above this value (see $\mathrm{ESI} \dagger$ for a detailed description of the $\mathrm{O}_{2}$ determination procedure).

\section{Results and discussion}

\section{Morphology of the LbL deposited $\mathrm{IrO}_{2}$ NP films on FTO electrodes}

High-resolution SEM images revealed that the FTO electrode surface was coated in an amorphous tissue-like structure upon deposition of $14 \mathrm{IrO}_{2} / \mathrm{PDDA}$-bilayers with uniform distribution of the $\mathrm{IrO}_{2}$ NPs across the film (white spots, 10-20 nm in size; see Fig. 1A and B). Direct comparison with SEM images of an unmodified FTO electrode clearly demonstrates that the contours of the LbL film follow the morphology of the underlying FTO surface (Fig. 1C and D). The observation of these $\mathrm{IrO}_{2}$ NPs in 10-20 nm clusters is fully consistent with both our TEM

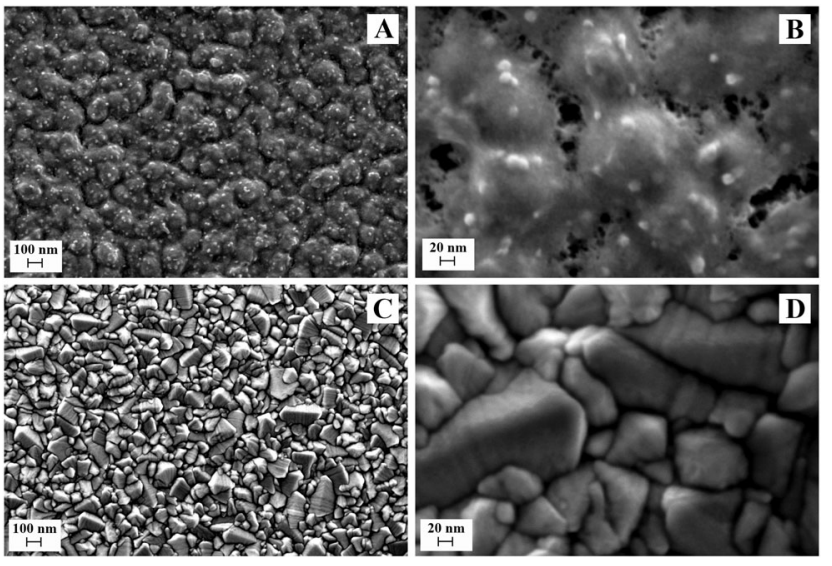

Fig. 1 Scanning electron microscopy (SEM) of the surface morphology of the $1 \mathrm{rO}_{2} /$ PDDA bilayer modified FTO electrodes. (A and B) SEM images at two different magnifications of the surface morphology of an FTO electrode modified using the layer-by-layer ( $L b L)$ methodology with $14 \mathrm{IrO}_{2} /$ PDDA-bilayers. ( $C$ and D) For comparison, SEM images at the same magnifications of the bare FTO electrode are shown.

images of the as-prepared colloidal $\mathrm{IrO}_{2} \mathrm{NP}$ solution herein (Fig. S1, ESI $\dagger$ ), and previous observations by Hoertz et al. ${ }^{9}$ that the individual $2 \mathrm{~nm} \mathrm{IrO}_{2}$ NPs form $c a .15 \mathrm{~nm}$ clusters due to the third carboxylate group of the citrate orientating itself away from the $\mathrm{IrO}_{2}$ surface and interacting with separate NPs. As no larger aggregates were observed by SEM in the $\mathrm{LbL} \mathrm{IrO}_{2} / \mathrm{PDDA}-$ films, we can conclude that the present method provides an efficient route to prepare tailored (in terms of surface coverage of electrocatalytic NPs in particular, discussed vide infra) NP films on an electrode surface that are free of aggregation. Furthermore, $\mathrm{IrO}_{2} / \mathrm{PDDA}$-modified FTO electrodes were subjected to prolonged sonication in ethanol-water to induce the removal of some of the NP film. TEM images of these solutions (Fig. S2, $\mathrm{ESI} \dagger$ ) revealed the presence of individual $2 \mathrm{~nm}$ NPs and aggregates of no more than 10-20 nm in size, again supporting the fact that the $\mathrm{IrO}_{2}$ clusters retain their original size and shapes post-LbL deposition.

\section{Spectro-electrochemistry of $\mathrm{LbL}$ deposited $\mathrm{IrO}_{2} \mathrm{NP}$ films on FTO electrodes}

Cyclic voltammetry (CV) of an $\mathrm{IrO}_{2}$-modified FTO electrode consisting of $10 \mathrm{IrO}_{2} / \mathrm{PDDA}$-bilayers in phosphate buffered solution $(\mathrm{pH} 7)$ is presented in Fig. 2A. The response (black CV curve), dominated by two reversible redox couples at $\sim 0.40 \mathrm{~V}$ and $\sim 0.72 \mathrm{~V} v s$. SHE, is in sharp contrast to the essentially featureless CV of the bare FTO electrode (red CV curve) under otherwise identical experimental conditions. The $\mathrm{CV}$ response of the $\mathrm{IrO}_{2} /$ PDDA-bilayers strongly resembles that previously reported for hydrous iridium oxide films (HIROFs). ${ }^{38-48}$ The two reversible redox couples are commonly attributed to the $\operatorname{Ir}(\mathrm{III}) / \mathrm{Ir}(\mathrm{IV})$ and $\operatorname{Ir}(\mathrm{Iv}) / \operatorname{Ir}(\mathrm{v})$ transitions, respectively, reflecting the multiple redox states available for the $\mathrm{IrO}_{2}$ centers. Interestingly, the electrochemical response strikingly contrasts with the one observed in flocculated films where the charge associated to the transformation between $\operatorname{Ir}(\mathrm{III}) / \operatorname{Ir}(\mathrm{IV})$ is higher than the one assigned to $\operatorname{Ir}(\mathrm{IV}) / \operatorname{Ir}(\mathrm{V})$. 

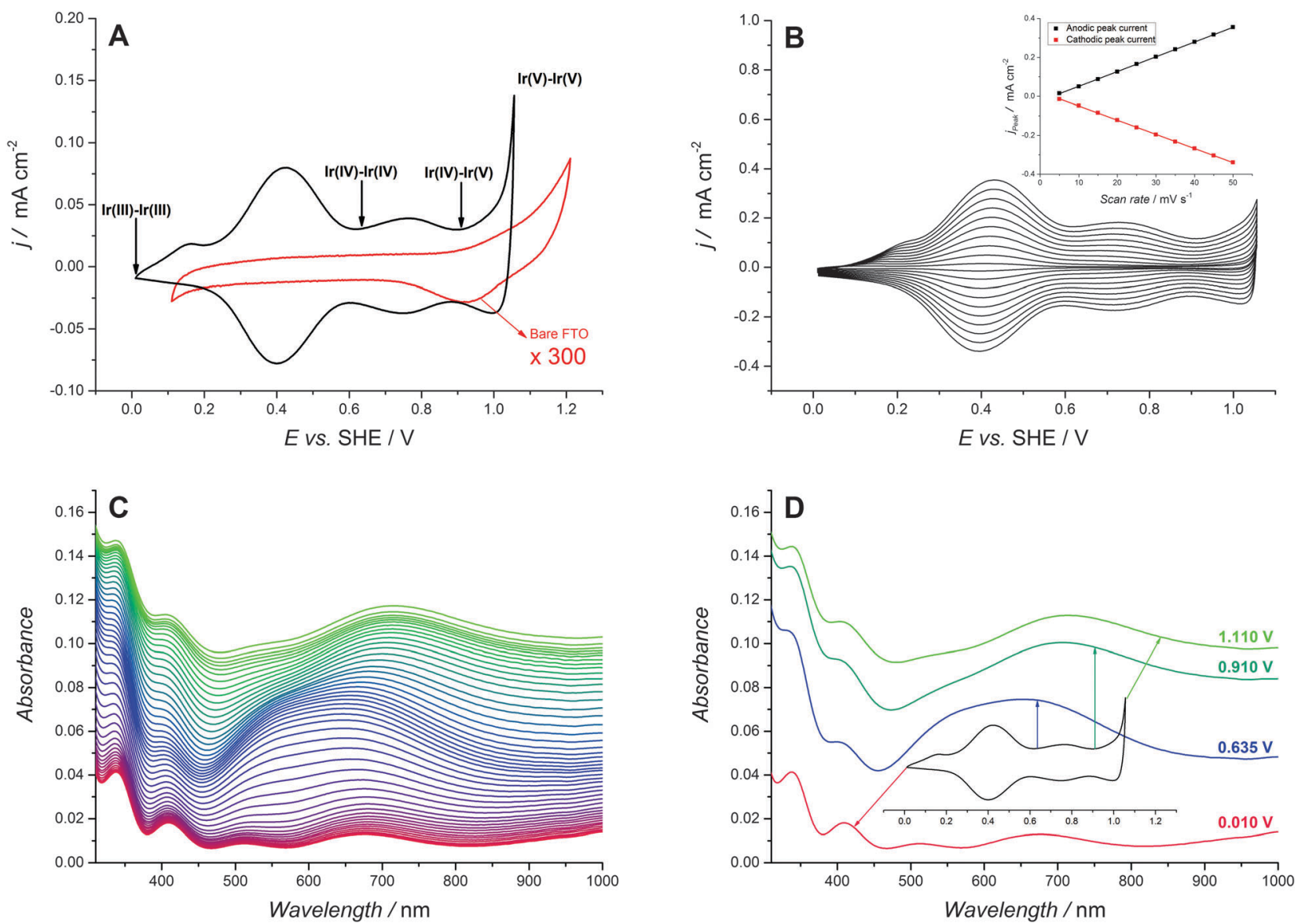

Fig. 2 Spectro-electrochemistry of the $\mathrm{IrO}_{2} / \mathrm{PDDA}$ bilayer modified FTO electrodes. (A) Comparison of the CV responses of a bare FTO electrode (red CV curve, magnified 300 times) and an FTO electrode modified with $10 \mathrm{IrO}_{2} /$ PDDA bilayers by LbL assembly (black CV curve). Scan rate used was $10 \mathrm{mV} \mathrm{s}^{-1}$. (B) Scan rate study of an FTO electrode modified with $8 \mathrm{IrO}_{2} /$ PDDA bilayers. Scan rates used: 5, 10, 15, 20, 25, 30, 35, 40, 45 and 50 mV s${ }^{-1}$. Inset: Linear dependence of the $\operatorname{Ir}(\mathrm{II}) / \mathrm{Ir}(\mathrm{IV})$ peak current density $\left(\mathrm{mA} \mathrm{cm} \mathrm{cm}^{-2}\right)$ vs. the scan rate $\left(\mathrm{mV} \mathrm{s}^{-1}\right)$. (C) Series of UV/vis spectra obtained at an FTO electrode modified with $14 \mathrm{IrO}_{2} /$ PDDA bilayers after a pre-treatment step that involved applying potentials over the range $0.010-1.110 \mathrm{~V}$ (from bottom to top) for $90 \mathrm{~s}$ via chronoamperometry in $25 \mathrm{mV}$ steps. (D) Representative UV/vis spectra at selected applied potentials highlighting the measured red shifts in the UV/vis spectra as the $\mathrm{IrO}_{2} \mathrm{NPs}$ in the $\mathrm{IrO}_{2} /$ PDDA bilayers were gradually oxidized at higher potentials. All CV data was obtained in $0.5 \mathrm{M}$ phosphate buffer solution $(\mathrm{pH}$ 7).

This unusual behavior, which is not explained in detail, reflects the different nature of the processes happening in the film obtained under such conditions. ${ }^{18,33}$ In this sense, the deposits obtained with stabilized particles exhibit a more ideal behavior, where the electron transfer occurs in a reversible manner. This reflects also the ability of the film to easily incorporate the anions required to compensate the change in the charge inside the film. Other features related to the CVs obtained herein are that (i) the charge associated with the second oxidation peak is lower than that of the first peak and (ii) the second peak appears broader. Previously, for HIROFs, the ratio between the charge associated with the first $(\operatorname{Ir}(\mathrm{III}) / \operatorname{Ir}(\mathrm{Iv}))$ and second $(\operatorname{Ir}(\mathrm{Iv}) / \operatorname{Ir}(\mathrm{V}))$ peaks has been found to be dependent on the $\mathrm{pH}$, the composition and the concentration of the electrolyte, but always remains less than $1 .^{42,48}$ This behaviour has been interpreted as the full oxidation of all $\mathrm{IrO}_{2}$ centers present from $\operatorname{Ir}(\mathrm{III})$ to $\operatorname{Ir}(\mathrm{Iv})$ at $\sim 0.40 \mathrm{~V}$, followed by only partial oxidation of the $\operatorname{Ir}(\mathrm{Iv})$ centers formed to $\operatorname{Ir}(\mathrm{v})$. Thus, during the $\operatorname{Ir}(\mathrm{III}) / \operatorname{Ir}(\mathrm{IV})$ transition, two $\operatorname{Ir}(\mathrm{III})$ centers, termed $\operatorname{Ir}(\mathrm{III})-\operatorname{Ir}(\mathrm{III})$, with adsorbed water molecules, i.e., $\mathrm{Ir}(\mathrm{III})-\mathrm{H}_{2} \mathrm{O}$, are oxidized to two $\operatorname{Ir}(\mathrm{Iv})$ centers, $\operatorname{Ir}(\mathrm{Iv})-\operatorname{Ir}(\mathrm{Iv})$, with adsorbed hydroxyl-groups, i.e., $\operatorname{Ir}(\mathrm{rv})-\mathrm{OH}$. Subsequently, these two $\operatorname{Ir}(\mathrm{Iv})$ centers may undergo full oxidation, forming an $\operatorname{Ir}(\mathrm{v})-\operatorname{Ir}(\mathrm{v})$ intermediate with double-bonded oxygen-groups attached, i.e., $\operatorname{Ir}(\mathrm{v})=\mathrm{O}$. In practice, the latter partial oxidation of the surface hydroxyl-groups is observed and attributed to ensemble effects that suppress the likelihood of two adjacent $\operatorname{Ir}(\mathrm{v})=\mathrm{O}$ moieties on the electrode surface. Additionally, these lateral repulsive interactions can also dictate the shape of the oxidation peaks and may be a contributory factor to the broadening of the $\operatorname{Ir}(\operatorname{Iv}) / \operatorname{Ir}(\mathrm{v})$ peak. Several other factors may also lead to the observed peak broadening including a distribution of formal potentials in the $\mathrm{LbL} \mathrm{film}^{49}$ or coupled ion-electron transfer processes. $^{50}$

Finally, as the potential applied is increased beyond $0.95 \mathrm{~V}$, the surface coverage of $\operatorname{Ir}(\mathrm{v})$ increases to the extent that the conditions for the formation of $\mathrm{O}-\mathrm{O}$ are reached and molecular oxygen $\left(\mathrm{O}_{2}\right)$ is released as a product of the electrocatalytic reaction. The cathodic peak at $\sim 0.95 \mathrm{~V}$ ( $v s$. SHE) is attributed 
to the reduction of unconsumed $\operatorname{Ir}(\mathrm{v})$ species, giving a rough estimate of the $\operatorname{Ir}(\mathrm{Iv}) / \operatorname{Ir}(\mathrm{v})$ redox potential. ${ }^{18}$

The effect of scan rate on the voltammetric peak current of the $\operatorname{Ir}(\mathrm{III}) / \mathrm{Ir}(\mathrm{IV})$ transition of an $\mathrm{IrO}_{2}$-modified FTO electrode consisting of eight $\mathrm{IrO}_{2} / \mathrm{PDDA}$-bilayers in phosphate buffered solution $(\mathrm{pH} 7)$ is presented in Fig. 2B. Both the anodic and cathodic peak current densities exhibited a linear relationship with the scan rate up to $50 \mathrm{mV} \mathrm{s}^{-1}$, indicating that electron transfer from the $\mathrm{IrO}_{2}$ centers to the electrode surface is a diffusion independent surface-controlled process in this scan rate range.

Interpretation of the CV data vide supra allows us to identify the required applied potentials necessary to generate either predominantly $\operatorname{Ir}(\mathrm{III})-\operatorname{Ir}(\mathrm{III}), \operatorname{Ir}(\mathrm{IV})-\operatorname{Ir}(\mathrm{IV}), \operatorname{Ir}(\mathrm{IV})-\operatorname{Ir}(\mathrm{v})$ or $\operatorname{Ir}(\mathrm{v})-\operatorname{Ir}(\mathrm{v})$ species in the LbL films. This precise control over the oxidation states of the $\mathrm{IrO}_{2}$ centers permits the use of spectroelectrochemistry to match the UV/vis spectroscopic response with the degree of oxidation of the LbL film (Fig. 2C). As discussed below, this is essential to accurately determine the surface coverage of $\mathrm{IrO}_{2}$ NPs in the film by UV/vis spectroscopy.
Potential step amperometry was used with applied potentials over the range $0.010-1.110 \mathrm{~V}$ ( $v s$. SHE) for $90 \mathrm{~s}$ in $25 \mathrm{mV}$ steps to an FTO electrode modified with $14 \mathrm{IrO}_{2} / \mathrm{PDDA}$-bilayers and the UV/vis spectra were recorded at each applied potential (Fig. 2C). At more positive applied potentials $(>0.600 \mathrm{~V} v s$. SHE) these spectra were strikingly different from that observed for the colloidal $\mathrm{IrO}_{2}$ NPs solution (Fig. S3, ESI $\dagger$ ). The latter are reported to consist of equimolar proportions of $\operatorname{Ir}(\mathrm{III})$ and $\operatorname{Ir}(\mathrm{IV}) .{ }^{9}$ However, as clearly illustrated in Fig. 2D, with successively more oxidizing potentials applied to the FTO electrode a shift to the red is observed and attributed to the generation of a mixture of $\operatorname{Ir}(\mathrm{Iv})$ and $\operatorname{Ir}(\mathrm{v})$ species in the LbL film.

\section{Optical and electrochemical determination of the $\mathrm{IrO}_{2} \mathrm{NP}$ surface coverage as a function of the number of bilayers deposited}

FTO electrodes modified with $14 \mathrm{IrO}_{2} / \mathrm{PDDA}$-bilayers appear a light blue color when freshly modified. However, visual inspection reveals that these electrodes turn colorless after "aging" in
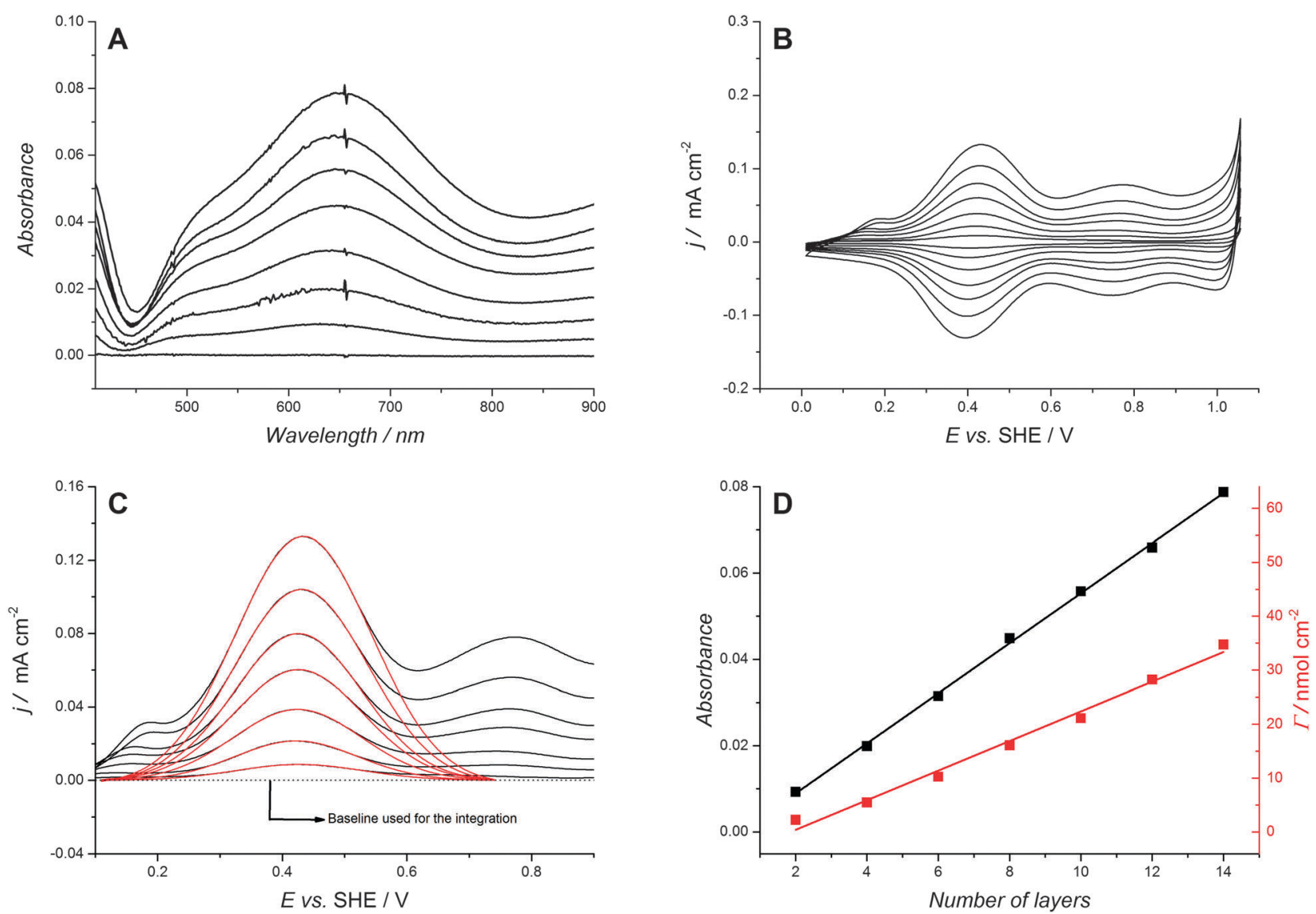

Fig. 3 Surface coverage determination of the total and "electrochemically active" $\mid \mathrm{rO}_{2}$ NPs present on the FTO electrode surface with increasing number of $\mathrm{IrO}_{2} / \mathrm{PDDA}$ bilayers deposited using the $\mathrm{LbL}$ approach. (A) UV/vis spectra of FTO electrodes modified with increasing numbers of IrO ${ }_{2} / \mathrm{PDDA}$ bilayers; $2,4,6,8,10,12$ and 14 from bottom to top. Prior to acquisition, each $\mathrm{IrO}_{2} / \mathrm{PDDA}$ bilayer modified FTO electrode was pre-treated by applying $0.635 \mathrm{~V}$ (vs. SHE) for $90 \mathrm{~s}$ using chronoamperometry. In this manner the $\mathrm{IrO}_{2} \mathrm{NPs}$ on each modified FTO electrode uniformly contained predominately $\operatorname{Ir}(\mathrm{IV})$, as detailed in the text, allowing accurate comparison of separate electrodes by UV/vis spectroscopy. (B) CV of the FTO electrodes with increasing numbers of $\mathrm{IrO}_{2} /$ PDDA bilayers as described in (A). (C) Fitting of the $\operatorname{Ir}(\mathrm{III}) / \operatorname{Ir}(\mathrm{IV})$ anodic peak using Gaussian fit functions to integrate the charge (Q/C) used to determine the surface coverage of electrochemically active $\mathrm{IrO}_{2} \mathrm{NPs}$ on the $\mathrm{FTO}$ electrodes $\left(\Gamma / \mathrm{nmol} \mathrm{cm}{ }^{-2}\right)$ with increasing numbers of $I r \mathrm{O}_{2} / \mathrm{PDDA}$ bilayers. (D) UV/vis peak absorbance (measured at $\lambda_{\max }=650 \mathrm{~nm}$; red squares) and $\operatorname{Ir}($ III)/Ir(IV) surface coverage (black squares) with increasing numbers of $\mathrm{IrO}_{2} /$ PDDA bilayers on the FTO electrode surface. 
ambient aerobic conditions for 5 days (Fig. S4, ESI $\dagger$ ). This "aging" process whereby the $\mathrm{IrO}_{2}$ NPs are slowly reduced by reaction perhaps with water trapped inside the film, substantially modifies the observed UV/vis spectra in comparison to a freshly modified electrode. Thus, in order to accurately compare several FTO electrodes modified with different numbers of bilayers by LbL on different days, each electrode was subjected to a pretreatment step prior to UV/vis characterization. The latter involved the application of an applied potential of $0.635 \mathrm{~V} v s$. SHE, so just after the first $\operatorname{Ir}(\mathrm{III}) / \operatorname{Ir}(\mathrm{Iv})$ redox process, for $90 \mathrm{~s}$ to produce an $\mathrm{IrO}_{2} / \mathrm{PDDA}$-film of predominately $\mathrm{Ir}(\mathrm{Iv})$ centers. The application of this potential visually oxidized the $\mathrm{IrO}_{2} \mathrm{NP}$ films back to a deeper blue colour and "normalized" the UV/vis responses of all modified electrodes in terms of the oxidation states of the $\mathrm{IrO}_{2}$ NPs therein. A comparison of these normalized UV/vis spectra as a function of the number of $\mathrm{IrO}_{2} / \mathrm{PDDA}$-bilayers deposited is presented in Fig. 3A. Furthermore, a plot of absorbance $v s$. the number of bilayers in Fig. 3D (black curve) is linear indicating the reproducible adhesion of each successive bilayer.

Further qualitative evidence of the "aging" of the $\mathrm{IrO}_{2} /$ PDDA-bilayers on the electrode surface upon storage in ambient conditions was provided by monitoring the open circuit potentials (OCPs) of the $\mathrm{IrO}_{2} / \mathrm{PDDA}$-bilayer modified electrodes with time. The precise values of the OCP measured in phosphate buffered solution $(\mathrm{pH} 7)$ varied slightly $( \pm 20 \mathrm{mV})$ between individually modified electrodes, but the trends in the shifts of OCP with time were universal. For all electrodes monitored, the value of the OCP substantially decreased (to more negative potentials) with aging, again in line with the reduction of the $\mathrm{IrO}_{2}$ NPs therein. This was especially evident for the thicker LbL-films (8-14 $\mathrm{IrO}_{2} / \mathrm{PDDA}$-bilayers) with 70-100 mV shifts after 5 days. In the thinner $\mathrm{LbL}$ films (2-4 $\mathrm{IrO}_{2} / \mathrm{PDDA}$-bilayers) the variation of the OCP was less pronounced (10-50 $\mathrm{mV}$ after 5 days).

Although UV/vis spectroscopy provides a qualitative measure of the linear increase in the number of $\mathrm{IrO}_{2}$ NPs present on the modified FTO electrodes with each successive bilayer (indicating reproducible adhesion), it does not verify if all $\mathrm{IrO}_{2}$ NPs present are electrochemically addressable, i.e., the $\mathrm{IrO}_{2} \mathrm{NPs}$ in the outermost layer are functional and in electrochemical communication with the underlying FTO electrode surface. The latter is a key factor when preparing electrodes containing relatively scarce materials such as Ir. A comparison of the electrochemical responses in phosphate buffered solution ( $\mathrm{pH} 7$ ) of a series of $\mathrm{IrO}_{2} / \mathrm{PDDA}$ bilayer modified electrodes with between 2 and 14 bilayers is shown in Fig. 3B.

Precise determination of the surface coverage $(\Gamma)$ of the electrochemically active $\mathrm{IrO}_{2}$ NPs present was achieved by integrating the charge $(Q)$ under the $\operatorname{Ir}(\mathrm{III}) / \operatorname{Ir}(\mathrm{IV})$ anodic peak at $0.2 \mathrm{~V}$ using Gaussian fit functions (see Fig. 3C) and applying the equation $\Gamma=Q / n F A$. An assumption was made that each $\mathrm{IrO}_{2}$ center transferred one electron, i.e., $n=1$. As clearly shown in Fig. 3D, the surface coverage increased linearly with successive bilayers, mirroring the linear increase in absorbance noted by UV/vis spectroscopy, and confirming that at the scan rate implemented $\left(10 \mathrm{mV} \mathrm{s}^{-1}\right)$ all of the $\mathrm{IrO}_{2}$ centers were electrochemically addressable.
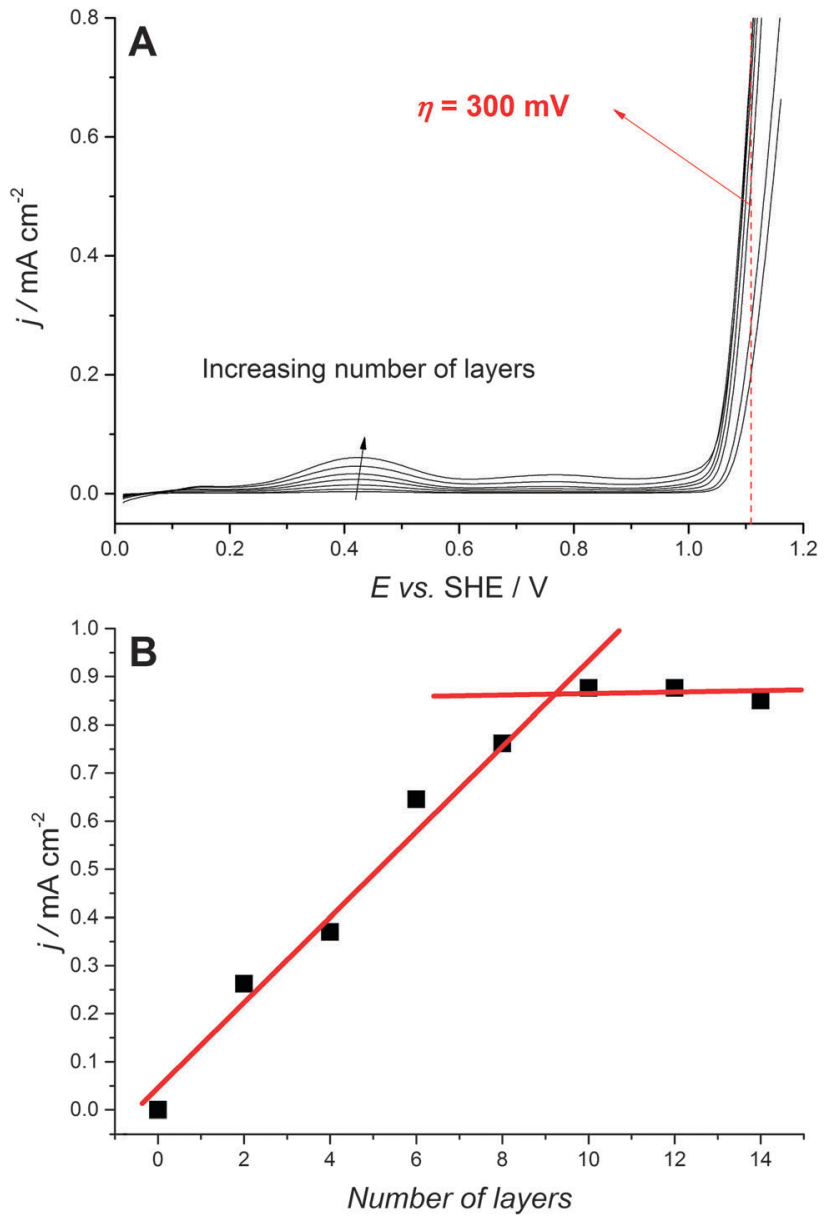

Fig. 4 Electrochemistry of the FTO modified electrodes at a potential where the OER takes place. (A) CVs of the FTO electrodes with increasing numbers of $\mathrm{IrO}_{2} / \mathrm{PDDA}$ bilayers. (B) Current density on the positive scan at $\eta=300 \mathrm{mV} v \mathrm{v}$. the thermodynamic potential for the OER as a function of the number of $\mathrm{IrO}_{2} / \mathrm{PDDA}$ bilayers.

To complete this picture, CVs of the modified electrodes were recorded using lower scan rates and scanned to higher upper potentials (Fig. 4A). The lower scan rates favor a lower ohmic drop, which becomes more important at potentials where the OER takes place. Fig. 4B depicts the current value in the positive scan at an overpotential of $300 \mathrm{mV}$ represented as a function of the number of $\mathrm{IrO}_{2} / \mathrm{PDDA}$-bilayers. The observed trend exhibits a saturation-like behavior, with a linear increase of the current density until approximately $10 \mathrm{IrO}_{2} /$ PDDA-bilayers are deposited LbL. Subsequently, the current density remains approximately constant upon the addition of further bilayers.

This saturation-like behavior contrasts with the monotonous linear increase observed in Fig. 3D, where the activity of the film was measured as the charge flowed during the transformation of $\operatorname{Ir}($ III) to $\operatorname{Ir}(\mathrm{IV})$. As the potential becomes higher than $\approx 1 \mathrm{~V}$, a significant amount of $\operatorname{Ir}(\mathrm{v})$ centers are formed with the subsequent release of $\mathrm{O}_{2}$ and protons. At this potential, diffusion controlled processes are involved, namely ingress of water to the film and egress of protons and $\mathrm{O}_{2}$ molecules from the film. Thus, as the 
film becomes thicker, it would seem that after 10 bilayers the rate of the OER reaches a saturation limit. Potentially, beyond 10 $\mathrm{IrO}_{2} / \mathrm{PDDA}$-bilayers diffusion of protons, $\mathrm{O}_{2}$ and water molecules through the film may to an extent be inhibited, acting as one cause of the observed saturation-like behaviour. A second possible cause is the potential drop within the film; while the inner layers are at a potential close to that of the electrode, the outer layers may be at lower potentials due to the $i \mathrm{R}$ drop within the film.

All in all, this LbL methodology provides a route to enhance by at least one order of magnitude the surface coverage of water oxidation catalyst deposited on the surface of the electrode by keeping intact the activity of the individual $\mathrm{IrO}_{2} \mathrm{NPs}$ within the film.

\section{Thermodynamic studies: super-Nernstian $\mathrm{pH}$ response and $\mathrm{O}_{2}$ evolution overpotentials as a function of $\mathbf{p H}$}

FTO electrodes modified with $8 \mathrm{IrO}_{2} / \mathrm{PDDA}$-bilayers were characterized by $\mathrm{CV}$ across the $\mathrm{pH}$ range 1 to 13 . The resulting voltammograms were plotted in Fig. 5A. In agreement with
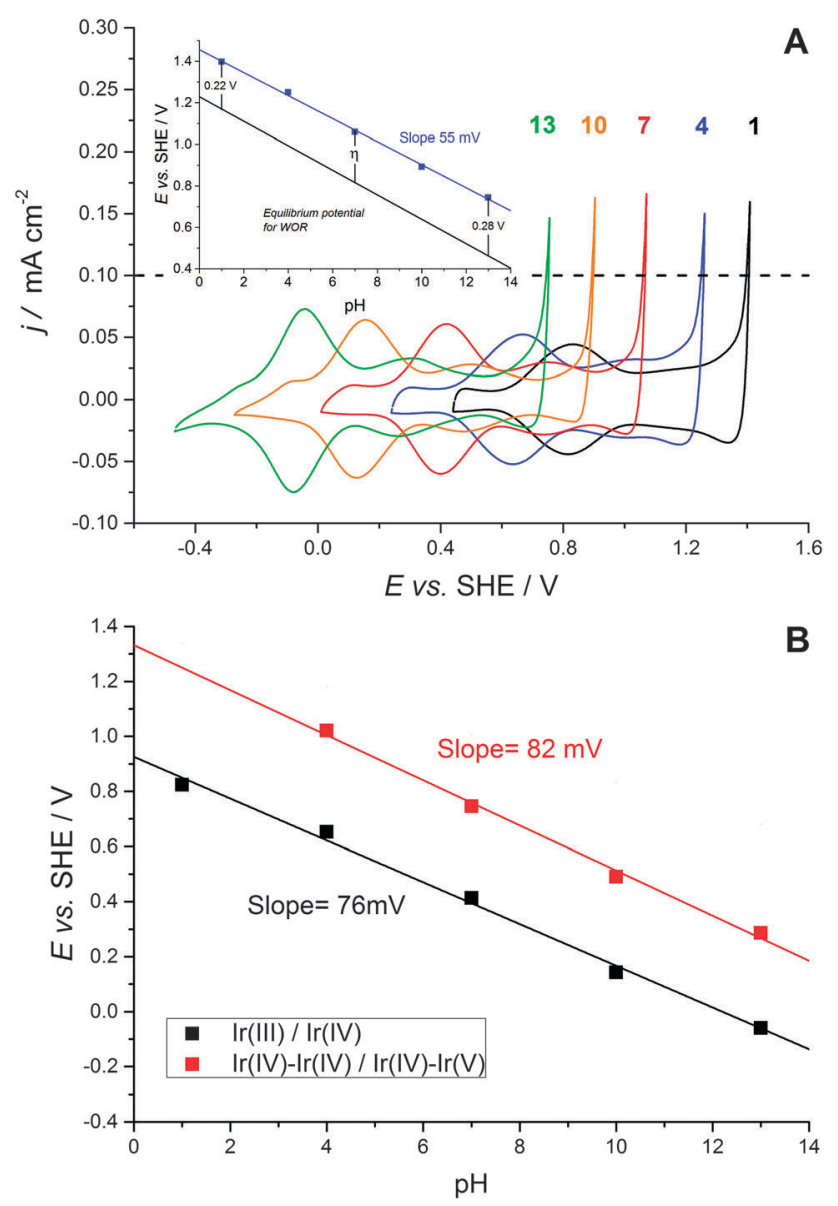

Fig. 5 Super-Nernstian $\mathrm{pH}$ response and OER onset potentials. (A) CVs of an FTO electrode modified with $8 \mathrm{IrO}_{2} / \mathrm{PDDA}$ bilayers measured in aqueous solutions at $\mathrm{pH} 1\left(0.1 \mathrm{M} \mathrm{HClO}_{4}\right), 4,7$ and 10 (0.5 M phosphate buffer solutions), and $13(0.1 \mathrm{M} \mathrm{NaOH})$. The scan rate used was $10 \mathrm{mV} \mathrm{s}^{-1}$. The inset in (A) highlights the $\mathrm{pH}$ dependence of the thermodynamic and experimentally observed onset potentials of the OER. (B) The $\mathrm{pH}$ dependence of the potentials associated with the anodic $\operatorname{Ir}($ III)/Ir(IV) (black squares) and cathodic Ir(Iv)-Ir(Iv)/Ir(Iv)-Ir(v) (red squares) redox transitions. several previous studies on HIROFs, ${ }^{42,43}$ and indeed various other metal oxide systems, ${ }^{51}$ a super-Nerstian $\mathrm{pH}$ dependence (i.e., the potential-pH dependence differs significantly from the expected $59 \mathrm{mV} \mathrm{pH}^{-1}$ predicted by a Nernstian analysis) was observed with the $\operatorname{Ir}(\mathrm{III})-\operatorname{Ir}(\mathrm{III}) / \operatorname{Ir}(\mathrm{IV})-\operatorname{Ir}(\mathrm{Iv})$ and $\operatorname{Ir}(\mathrm{Iv})-\operatorname{Ir}(\mathrm{Iv}) / \operatorname{Ir}(\mathrm{IV})-\operatorname{Ir}(\mathrm{v})$ redox transitions shifting negatively by 76 and $82 \mathrm{mV} \mathrm{pH}^{-1}$ with decreasing acidity, respectively (Fig. 5B). In contrast, the onset potential of the OER displayed a typical quasi-Nernstian response shifting negatively $55 \mathrm{mV} \mathrm{pH}^{-1}$ with decreasing acidity (Fig. 5A, inset). Thus, as the Ir redox transitions shift to more negative potentials to a greater degree than the OER onset potential as a function of $\mathrm{pH}$, a consequence is the much clearer separation of the $\operatorname{Ir}(\mathrm{III}) / \operatorname{Ir}(\mathrm{IV})$ and $\operatorname{Ir}(\mathrm{IV})-\operatorname{Ir}(\mathrm{IV}) / \operatorname{Ir}(\mathrm{IV})-\operatorname{Ir}(\mathrm{v})$ redox transitions from the OER onset potential at neutral or alkaline conditions. The origin of the super-Nernstian behavior may be explained as follows: the oxidation from $\mathrm{Ir}(\mathrm{III})-\mathrm{OH}_{2}$ to $\operatorname{Ir}(\mathrm{IV})-\mathrm{OH}$ releases one proton and one electron according to the stoichiometry of the reaction. Moreover, as a more oxidized and therefore more acidic center is generated, a fraction of protons is released from the films according to the acid-base equilibrium. Thus, a proton/ electron ratio higher than 1 is obtained during the overall transformation from Ir(III) to Ir(IV), resulting in a super-Nernstian dependence of the potential. The same reasoning applies for the second redox process labelled as the $\operatorname{Ir}(\mathrm{Iv}) / \operatorname{Ir}(\mathrm{Iv}) / \operatorname{Ir}(\mathrm{Iv})-\operatorname{Ir}(\mathrm{v})$. An in-depth mechanistic study on this topic for the LbL-deposited $\mathrm{IrO}_{2} / \mathrm{PDDA}$ films herein is beyond the scope of this article and the reader is referred to recent mechanistic work by Ahlberg and co-workers in this regard. ${ }^{47,48}$

A comparison of the OER onset and thermodynamic potentials for $\mathrm{O}_{2}$ evolution (inset Fig. 5A) highlighted an essentially $\mathrm{pH}$-independent overpotential $(\eta)$, varying slightly from 0.22 to $0.28 \mathrm{~V}$ moving from acidic to alkaline conditions, for $\mathrm{IrO}_{2} /$ PDDA-bilayers FTO electrodes. This value is either lower or comparable to those reported previously for other $\mathrm{IrO}_{2} \mathrm{NP}$-modified electrodes. ${ }^{18,19,21-23}$

Finally, a progressive decrease in the intensity of the $\operatorname{Ir}(\mathrm{III}) /$ $\operatorname{Ir}(\mathrm{Iv})$ peak is observed from basic to acidic $\mathrm{pH}$ values. However, as the intensity of the peak decreases it concurrently broadens, ultimately rendering a peak with approximately the same charge, and thereby providing the same number of active centers. As previously discussed, the catalytic centers possess acid-base properties, thus changes in the $\mathrm{pH}$ necessarily affect the proportion of acid/base species which take part in the charge transfer reaction. As a consequence, at lower $\mathrm{pH}$ values a higher proportion of protonated species are present in the film, promoting lateral interactions and therefore broadening of the peaks.

\section{OER efficiency and $\mathrm{IrO}_{2} /$ PDDA film stability studies}

Bulk electrolysis experiments were carried out with FTO electrodes modified with $14 \mathrm{IrO}_{2} / \mathrm{PDDA}$-bilayers in $0.1 \mathrm{M} \mathrm{HClO}_{4}$ (pH 1), $0.5 \mathrm{M}$ phosphate buffer ( $\mathrm{pH} 7)$ and $0.1 \mathrm{M} \mathrm{NaOH}(\mathrm{pH} 13)$ aqueous solutions. The concentration of the buffer species in solution ensures that the $\mathrm{pH}$ as well as the thermodynamic driving force for the OER remained approximately constant.

During bulk electrolysis the Fermi level of the FTO electrode is controlled by the voltage source, and the Fermi levels of all of 


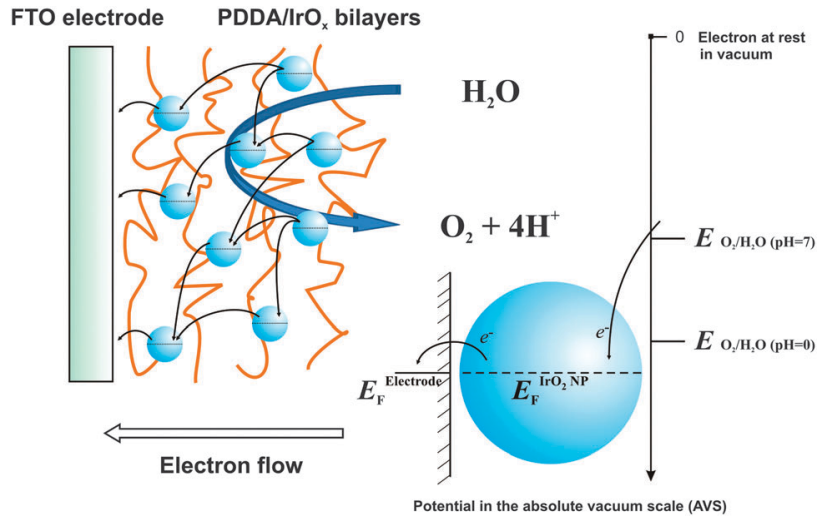

Fig. 6 Schematic of electron transfer during the OER for an FTO electrode modified with PDDA/IrO 2 bilayers. Electron transfer between the $\mathrm{IrO}_{2}$ centers with the film proceeds via a tunneling mechanism through the insulating polymer structure.

the electrochemically addressable $\mathrm{IrO}_{2} \mathrm{NPs}$ in the LbL-deposited film shift to that set potential by Fermi level equilibration. In this manner, at each $\mathrm{pH}$ condition, an overpotential $(\eta=$ $+400 \mathrm{mV}$ ) was applied. As depicted in Fig. 6, although the Fermi levels of the electrode and $\mathrm{IrO}_{2}$ NPs equilibrate, those of the $\mathrm{O}_{2} / \mathrm{H}_{2} \mathrm{O}$ redox couple in solution do not. The latter arises as the kinetics of the rate of discharging the $\mathrm{IrO}_{2} \mathrm{NPs}$, by electron transfer to the electrode surface facilitated by tunneling of electrons between $\mathrm{IrO}_{2}$ NPs in the film due to the overlapping high densities of states of the metallic oxides,${ }^{52}$ are far superior to the kinetics of charging the $\mathrm{IrO}_{2} \mathrm{NPs}$, via the OER at the surface of each $\mathrm{IrO}_{2}$ NP. Thus, a constant thermodynamic driving force is present that drives electron transfer efficiently to the electrode surface.

A classic bulk electrolysis cell configuration was utilized, as described in the Experimental section and shown in Fig. S5, ESI. $\dagger$ These experiments had the dual role of (i) determining the Faradaic efficiency of these $\mathrm{IrO}_{2} \mathrm{NP}$ modified electrodes towards the OER and (ii) determining the stability of the LbLdeposited $\mathrm{IrO}_{2} / \mathrm{PDDA}$ bilayers on the FTO electrode surface. It should be noted that the stability of these electrodes is likely to be loading-dependent. Therefore, some variations in the trends reported below may be observed for FTO electrodes modified with less or more $\mathrm{IrO}_{2} / \mathrm{PDDA}$ bilayers.

The Faradaic efficiency of the OER at each $\mathrm{pH}$ studied for FTO electrodes modified with $14 \mathrm{IrO}_{2} / \mathrm{PDDA}$-bilayers was determined by comparing the actual amounts of $\mathrm{O}_{2}$ evolved $\left(\eta_{\mathrm{O}_{2} \text { (evolved) }} / \mu \mathrm{mol}\right)$, determined using a FOXY fluorescent $\mathrm{O}_{2}$ sensor from Ocean Optics (see Fig. S6, ESI $\dagger$ ), vs. the theoretical amounts of $\mathrm{O}_{2}$ expected based on the quantity of charge passed $(Q=6.85 \mathrm{C}$ for each electrode tested) during bulk electrolysis (Fig. 7). The results are summarized in Tables S1 and S2, ESI, $\dagger$ and reveal that under acidic and neutral conditions the efficiency of $\mathrm{O}_{2}$ evolution approaches $100 \%$ within experimental error, but dips below $90 \%$ under alkaline conditions. The trends in stability of the $\mathrm{IrO}_{2} / \mathrm{PDDA}$ modified FTO electrodes towards $\mathrm{O}_{2}$ evolution with $\mathrm{pH}$ are clearly evident from voltammetry (Fig. 7). The measured currents $(\eta=+400 \mathrm{mV})$ exhibited steady-state behavior during electrolysis (Fig. 7A and B), and marginal changes in the CVs taken pre- and post-electrolysis were observed, at $\mathrm{pH} 1$ and pH 7 (Fig. 7D and E). Thus, under acidic and neutral conditions the LbL-modified electrodes were robust, exhibiting no meaningful losses in catalytic efficiency during bulk electrolysis.

However, at $\mathrm{pH} 13$, the measured current gradually decreased with time (Fig. 7C) and the CVs taken pre- and post-electrolysis were substantially different (Fig. 7F), both indicative of poor stability in alkaline media. The latter loss of stability may reflect decomposition of the $\mathrm{IrO}_{2}$ NPs, with formation of less reactive species under alkaline conditions, or simply a chemical degradation of the PDDA polymer that binds the $\mathrm{IrO}_{2}$ NPs to the FTO electrode surface. Considering the high stability of $\mathrm{IrO}_{2} \mathrm{NPs}$ and their low tendency to corrode in alkaline media, ${ }^{20}$ the leaching of the $\mathrm{IrO}_{2}$ NPs from the electrode surface is more likely. Indeed, Stevens and co-workers described that, in the presence of a strong base, quaternary ammonium salts may undergo a 1,2-rearrangement. This reaction, commonly referred to as the Stevens rearrangement, ${ }^{53-55}$ results in the formation of a tertiary amine which at basic conditions is neutral. Thus, the electrostatic forces binding the $\mathrm{IrO}_{2} / \mathrm{PDDA}$ bilayers together weaken or disappear with time under alkaline conditions, leading to a terminal loss of film stability and gradual removal of catalytic $\mathrm{IrO}_{2} \mathrm{NPs}$ from the surface of the FTO electrode. This loss of stability under alkaline conditions also explains the lower Faradaic efficiencies determined under these conditions (see Table S2, ESI $\dagger$ ). Additional experiments involved testing the stability of electrode responses at longer times and higher overpotentials to push the electrodes to their working limits. Fig. S7A and C, ESI, $\dagger$ shows that at $\eta=+600 \mathrm{mV}$ the catalytic current only decreases by $15 \%$ of the initial value after 12 hours of electrolysis under acidic conditions. However, the catalytic current under neutral conditions was seen to degrade under these harsher experimental conditions, Fig. S7B and D, ESI. $\dagger$ Thus, improvements are necessary to stabilize the LbL-deposited $\mathrm{IrO}_{2} \mathrm{NP}$ films at all $\mathrm{pH}$ values, but especially under alkaline conditions, while retaining permeability to water molecules, $\mathrm{O}_{2}$ and protons. In this regard, future work will involve replacing PDDA with other cationic polymer candidates typically used in LbL methodologies, such as poly(aniline) (PANI), poly(ethylene imine) (PEI), poly-L-lysine, etc. This inherent versatility of a LbL approach is a major advantage to ensure the preparation of stable and catalytically active $\mathrm{IrO}_{2}$ modified OER electrodes over the entire $\mathrm{pH}$ range.

The maximum current density obtained by the FTO electrode modified with $14 \mathrm{IrO}_{2} / \mathrm{PDDA}$ bilayers at $\eta=+400 \mathrm{mV}$ under acidic conditions was $1.5 \mathrm{~mA} \mathrm{~cm}{ }^{-2}$ (Fig. 7A). Much higher current densities at $\eta=+400 \mathrm{mV}$, in the region of 30 to $100 \mathrm{~mA} \mathrm{~cm}^{-2}$, are required to implement our LbL modified FTO electrodes in solar or electrolyzer technology. To achieve this, future work will involve changing the experimental conditions (e.g., by varying the concentration of colloidal $\mathrm{IrO}_{2}$ NPs in the dipping solution or replacing and/or using an alternative polymer to PDDA, as noted vide supra) to increase the number of active centres per bilayer and improve the relatively low surface coverages of catalytic $\mathrm{IrO}_{2} \mathrm{NPs}$ herein $\left(10^{-9} \mathrm{nmol} \mathrm{cm} \mathrm{cm}^{-2}\right)$ one order of magnitude. Also, to highlight the activity of the $\mathrm{IrO}_{2} \mathrm{NPs}$ in the 

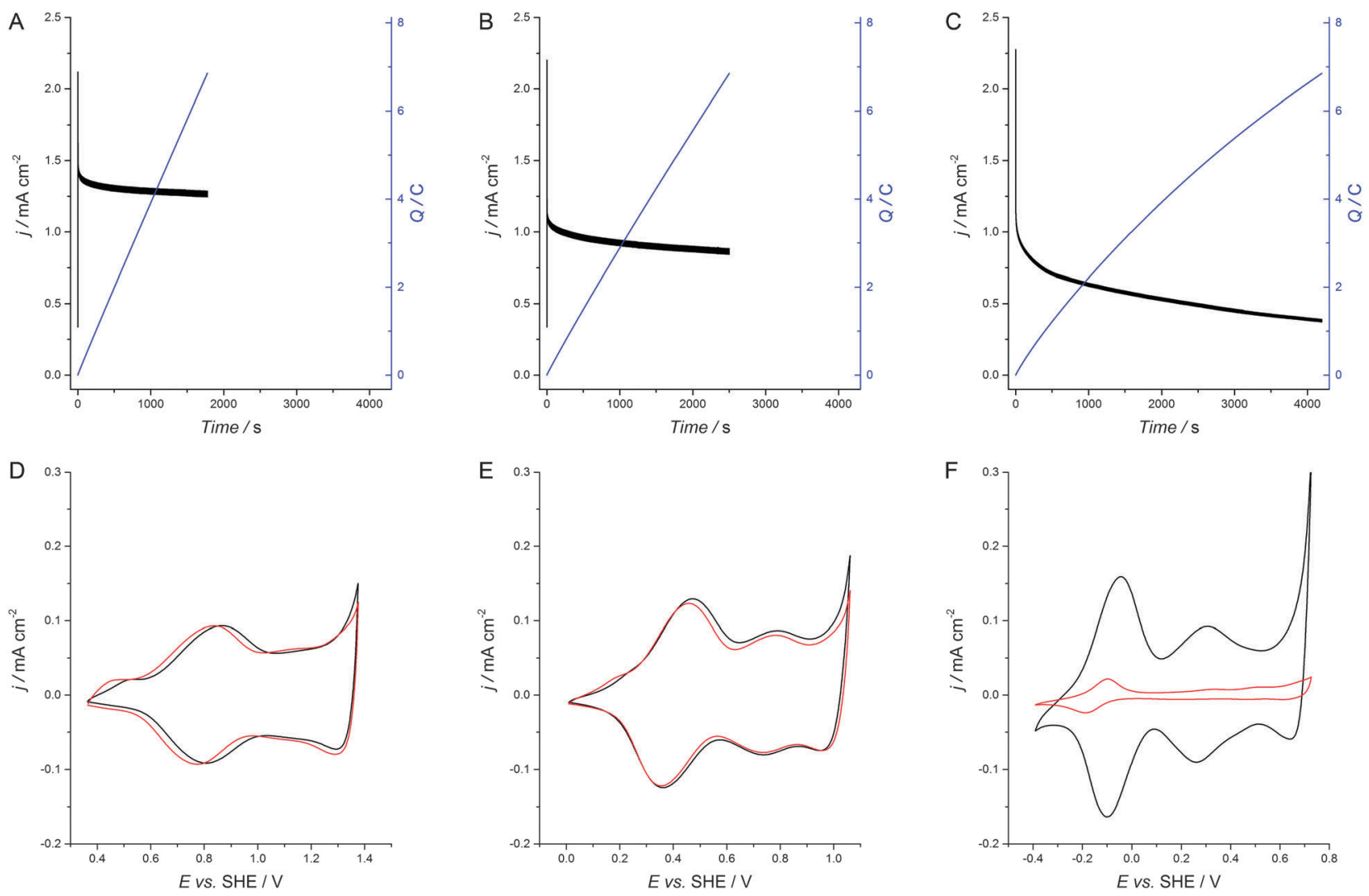

Fig. 7 Bulk electrolysis experiments: OER efficiency and $1 \mathrm{rO}_{2} / \mathrm{PDDA}$ film stability studies. (A-C) Chronoamperometric plots of the current (black line) and charge (blue line) during water electrolysis using an FTO electrode modified with $14 \mathrm{IrO}_{2} / \mathrm{PDDA}$ bilayers in a classic bulk electrolysis cell (see Fig. S6, $\mathrm{ESI} \dagger$ ). In each case an overpotential $(\eta)$ of $+400 \mathrm{mV}$ vs. the thermodynamic potential for the OER was applied to the working electrode. The experiments were carried out in (A) $0.1 \mathrm{M} \mathrm{HClO}_{4}$, (B) $0.5 \mathrm{M}$ phosphate buffer solution (pH 7) and (C) $0.1 \mathrm{M} \mathrm{NaOH}$ with applied potentials of $1.57,1.22$ and 0.80 vs. SHE, respectively. The non compensated resistance for the three systems measured by impedance spectroscopy was $46 \Omega$, $48 \Omega$ and $37 \Omega$ respectively. The figures (D-F) depict the CVs recorded before (black line) and after (red line) electrolysis for the systems described in (A-C). The scan rate used was $10 \mathrm{mV} \mathrm{s}^{-1}$.

PDDA-polymer environment, a comparison was made by normalizing the current density $\left(1.5 \mathrm{~mA} \mathrm{~cm}{ }^{-2}\right)$ with the surface coverage $\left(35 \mathrm{nmol} \mathrm{cm}^{-2}\right.$ ) for bulk electrolysis carried out under acidic conditions (see Fig. 7A). A value of $0.22 \mathrm{~A} \mathrm{~cm}^{-2} \mathrm{mg}^{-1}$ was attained and this is close to the value of $0.3 \mathrm{~A} \mathrm{~cm}^{-2} \mathrm{mg}^{-1}$ reported by Millet and co-workers for an optimized system for water electrolysis. ${ }^{56}$ Thus, by further optimizing our experimental conditions to find just a single order of magnitude increase in the surface coverage of $\mathrm{IrO}_{2} \mathrm{NPs}$, and maintaining or increasing the activity of the individual $\mathrm{IrO}_{2} \mathrm{NPs}$ under these optimised conditions, our methodology will be viable for applications in solar and electrolyzer applications.

\section{Conclusions}

Layer-by-layer assembly of catalytic $\mathrm{IrO}_{2} \mathrm{NPs}$ represents a flexible, reproducible and scalable approach to developing OER electrodes. Crucially the resulting "tissue-like" amorphous films allow the as-synthesized $\mathrm{IrO}_{2} \mathrm{NPs}$ trapped therein to retain their original shapes and sizes. The latter is key to maintaining the intrinsic catalytic activity of the $\mathrm{IrO}_{2}$ NPs and this is seen in the low overpotentials ( 0.22 to $0.28 \mathrm{~V}$ ) necessary to achieve $\mathrm{O}_{2}$ evolution across the $\mathrm{pH}$ range 1-13 studied herein. The surface coverage of electrochemically addressable iridium centers can be finely tuned by incorporation of additional $\mathrm{IrO}_{2} / \mathrm{PDDA}$ bilayers improving the kinetics of the OER substantially, as shown by the CV at high potentials. The chosen positively charged polymer in this study, PDDA, is stable under acidic and neutral conditions. Although the films discussed herein are unstable in alkaline conditions the flexibility inherent to a layer-by-layer approach means that in future studies we simply need to replace PDDA with a positively charged polymer that can resist basic conditions. The insights gained in this study will form the basis of a new approach to developing a flexible and scalable methodology to prepare large-scale OER electrodes using ink-jet printing technology.

\section{Acknowledgements}

Financial support is acknowledged from the project Polswiss PSPB-35/2010. This publication has emanated from research by M.D.S. supported in part by a research grant from Science Foundation Ireland (SFI) under Grant Number 13/SIRG/2137. 


\section{Notes and references}

1 A. J. Bard and M. A. Fox, Acc. Chem. Res., 1995, 28, 141-145.

2 V. Balzani, G. Bergamini, S. Campagna and F. Puntoriero, in Photochem. Photophys. Coord. Compd. I, ed. V. Balzani and S. Campagna, Springer, Berlin Heidelberg, 2007, vol. 280, pp. 1-36.

3 M. P. O’Neil, M. P. Niemczyk, W. A. Svec, D. Gosztola, G. L. Gaines and M. R. Wasielewski, Science, 1992, 257, 63-65.

4 H. Yamazaki, A. Shouji, M. Kajita and M. Yagi, Coord. Chem. Rev., 2010, 254, 2483-2491.

5 A. Sartorel, M. Carraro, F. M. Toma, M. Prato and M. Bonchio, Energy Environ. Sci., 2012, 5, 5592-5603.

6 P. K. Dutta and S. K. Das, J. Am. Chem. Soc., 1997, 119, 4311-4312.

7 N. D. Morris and T. E. Mallouk, J. Am. Chem. Soc., 2002, 124, 11114-11121.

8 N. D. Morris, M. Suzuki and T. E. Mallouk, J. Phys. Chem. A, 2004, 108, 9115-9119.

9 P. G. Hoertz, Y.-I. Kim, W. J. Youngblood and T. E. Mallouk, J. Phys. Chem. B, 2007, 111, 6845-6856.

10 M. Hara, C. C. Waraksa, J. T. Lean, B. A. Lewis and T. E. Mallouk, J. Phys. Chem. A, 2000, 104, 5275-5280.

11 L. Liao, J. Zhu, X. Bian, L. Zhu, M. D. Scanlon, H. H. Girault and B. Liu, Adv. Funct. Mater., 2013, 23, 5326-5333.

12 M. D. Scanlon, X. Bian, H. Vrubel, V. Amstutz, K. Schenk, X. Hu, B. Liu and H. H. Girault, Phys. Chem. Chem. Phys., 2013, 15, 2847-2857.

13 M. S. Faber and S. Jin, Energy Environ. Sci., 2014, 7, 3519-3542.

14 L. Liao, S. Wang, J. Xiao, X. Bian, Y. Zhang, M. D. Scanlon, X. Hu, Y. Tang, B. Liu and H. H. Girault, Energy Environ. Sci., 2014, 7, 387-392.

15 W. Rüttinger and G. C. Dismukes, Chem. Rev., 1997, 97, 1-24.

16 J. Rossmeisl, A. Logadottir and J. K. Nørskov, Chem. Phys., 2005, 319, 178-184.

17 H. Dau, C. Limberg, T. Reier, M. Risch, S. Roggan and P. Strasser, ChemCatChem, 2010, 2, 724-761.

18 T. Nakagawa, C. A. Beasley and R. W. Murray, J. Phys. Chem. C, 2009, 113, 12958-12961.

19 T. Nakagawa, N. S. Bjorge and R. W. Murray, J. Am. Chem. Soc., 2009, 131, 15578-15579.

20 Y. Zhao, E. A. Hernandez-Pagan, N. M. Vargas-Barbosa, J. L. Dysart and T. E. Mallouk, J. Phys. Chem. Lett., 2011, 2, 402-406.

21 Y. Zhao, N. M. Vargas-Barbosa, E. A. Hernandez-Pagan and T. E. Mallouk, Small, 2011, 7, 2087-2093.

22 M.-C. Chuang and J.-a. A. Ho, RSC Adv., 2012, 2, 4092-4096.

23 H.-Y. Hsiao and M.-C. Chuang, Electrochim. Acta, 2014, 137, 190-196.

24 N. Mirbagheri, J. Chevallier, J. Kibsgaard, F. Besenbacher and E. E. Ferapontova, ChemPhysChem, 2014, 15, 2844-2850.

25 A. Harriman, M.-C. Richoux, P. A. Christensen, S. Mosseri and P. Neta, J. Chem. Soc., Faraday Trans. 1, 1987, 83, 3001-3014.

26 A. Harriman, I. J. Pickering, J. M. Thomas and P. A. Christensen, J. Chem. Soc., Faraday Trans. 1, 1988, 84, 2795-2806.

27 L. M. Gajić-Krstajić, T. L. Trišović and N. V. Krstajić, Corros. Sci., 2004, 46, 65-74.

28 A. T. Bell, Science, 2003, 299, 1688-1691.
29 D. M. Kaschak and T. E. Mallouk, J. Am. Chem. Soc., 1996, 118, 4222-4223.

30 M. Yagi, E. Tomita and T. Kuwabara, J. Electroanal. Chem., 2005, 579, 83-88.

31 M. Yagi, E. Tomita, S. Sakita, T. Kuwabara and K. Nagai, J. Phys. Chem. B, 2005, 109, 21489-21491.

32 T. Kuwabara, E. Tomita, S. Sakita, D. Hasegawa, K. Sone and M. Yagi, J. Phys. Chem. C, 2008, 112, 3774-3779.

33 K. E. Michaux and R. W. Murray, Langmuir, 2013, 29, 12254-12258.

34 S. D. Tilley, M. Cornuz, K. Sivula and M. Grätzel, Angew. Chem., Int. Ed., 2010, 49, 6405-6408.

35 M. A. Petit and V. Plichon, J. Electroanal. Chem., 1998, 444, 247-252.

36 A. Lesch, F. Cortés-Salazar, V. Amstutz, P. Tacchini and H. H. Girault, Anal. Chem., 2015, 87, 1026-1033.

37 A. Lesch, F. Cortés-Salazar, V. C. Bassetto, V. Amstutz and H. H. Girault, Chimia, 2015, 69, 284-289.

38 D. N. Buckley and L. D. Burke, J. Chem. Soc., Faraday Trans. 1, 1975, 71, 1447-1459.

39 D. N. Buckley and L. D. Burke, J. Chem. Soc., Faraday Trans. 1, 1976, 72, 2431-2440.

40 D. N. Buckley, L. D. Burke and J. K. Mulcahy, J. Chem. Soc., Faraday Trans. 1, 1976, 72, 1896-1902.

41 L. D. Burke and D. P. Whelan, J. Electroanal. Chem. Interfacial Electrochem., 1981, 124, 333-337.

42 B. E. Conway and J. Mozota, Electrochim. Acta, 1983, 28, 9-16.

43 L. D. Burke, J. K. Mulcahy and D. P. Whelan, J. Electroanal. Chem. Interfacial Electrochem., 1984, 163, 117-128.

44 L. D. Burke and D. P. Whelan, J. Electroanal. Chem. Interfacial Electrochem., 1984, 162, 121-141.

45 P. G. Pickup and V. I. Birss, J. Electroanal. Chem. Interfacial Electrochem., 1988, 240, 171-183.

46 C. Bock and V. I. Birss, Electrochim. Acta, 2001, 46, 837-849.

47 P. Steegstra and E. Ahlberg, Electrochim. Acta, 2012, 76, 26-33.

48 P. Steegstra, M. Busch, I. Panas and E. Ahlberg, J. Phys. Chem. C, 2013, 117, 20975-20981.

49 M. J. Honeychurch and G. A. Rechnitz, Electroanalysis, 1998, 10, 285-293.

50 J. C. Myland and K. B. Oldham, J. Electroanal. Chem., 2002, 530, 1-9.

51 M. E. G. Lyons, R. L. Doyle and M. P. Brandon, Phys. Chem. Chem. Phys., 2011, 13, 21530-21551.

52 J. Kim, B.-K. Kim, S. K. Cho and A. J. Bard, J. Am. Chem. Soc., 2014, 136, 8173-8176.

53 T. S. Stevens, E. M. Creighton, A. B. Gordon and M. MacNicol, J. Am. Chem. Soc., 1928, 3193-3197.

54 J. L. Dunn and T. S. Stevens, J. Am. Chem. Soc., 1932, 1926-1931.

55 J. A. Vanecko, H. Wan and F. G. West, Tetrahedron, 2006, 62, 1043-1062.

56 P. Millet, R. Ngameni, S. A. Grigoriev, N. Mbemba, F. Brisset, A. Ranjbari and C. Etiévant, Int. J. Hydrogen Energy, 2010, 35, 5043-5052. 